\title{
Modeling Carbonation of High-Level Waste Tank Integrity and Closure
}

\author{
K. G. Brown ${ }^{1, a}$, J. Arnold ${ }^{1}$, S. Sarkar ${ }^{1}$, G. Flach ${ }^{2}$, H. van der Sloot $^{3}$, J.C.L. Meeussen ${ }^{4}$, D. S. Kosson ${ }^{1}$ \\ ${ }^{1}$ Vanderbilt University, School of Engineering \& CRESP III, Nashville, TN 37235 \\ ${ }^{2}$ Savannah River National Laboratory, Aiken, SC 29808 \\ ${ }^{3}$ Hans van der Sloot Consultancy, 1721 BV Langedijk, The Netherlands \\ ${ }^{4}$ NRG (Nuclear Research and Consultancy Group), 1755 ZG PETTEN, The Netherlands
}

\begin{abstract}
The Cementitious Barriers Partnership (CBP) is focused on reducing uncertainties in current methodologies for assessing cementitious barrier performance and increasing the consistency and transparency in the assessment process. One important set of US Department of Energy challenges is assessing the integrity and closure of the high-level waste (HLW) tanks that currently store millions of gallons of highly radioactive wastes. Many of these tanks are decades past their design lives, have leaked or been overfilled, and must be emptied and closed to satisfy regulatory agreements. Carbonation-induced corrosion has been identified as a primary degradation and possible failure mechanism for the HLW tanks prior to closure. After closure the impact of carbonation (and concurrent oxidation) may be to increase the release and short-range transport of contaminants of concern. HLW tanks may be significantly empty for many years (and possibly decades) prior to closure; the performance of the closed tank over centuries, if not millennia, must be assessed to evaluate the potential release of residual radionuclides to the environment.

CBP is developing models to evaluate a representative HLW tank closure scenario including the potential impacts of carbonation on waste tanks prior to and post closure. CBP modeling tools, including LeachXSTM/ORCHESTRA, are being used to simulate waste tank carbonation, major constituent leaching, and contaminant releases to evaluate the source term and near-field conditions. Simulations presented here include sensitivity analysis for uncracked concrete to varying input parameters including composition, effective diffusivities, and thermodynamic parameters.
\end{abstract}

\section{Introduction}

A set of important challenges to the U.S. Department of Energy (USDOE) is assessing the integrity of and ultimately closing the high-level waste (HLW) tanks that store millions of gallons of highly radioactive wastes. Many of these tanks are decades past their design lives, have leaked or been overfilled, and must be emptied and closed to satisfy regulatory agreements. Carbonation-induced corrosion has been identified as a primary degradation and possible failure mechanism for the HLW tanks. After closure carbonation may increase the release and transport of contaminants of concern. HLW tanks may be largely empty for many years prior to closure; the performance of the closed

This is an Open Access article distributed under the terms of the Creative Commons Attribution License 2.0, which permits unrestricted use, distribution, and reproduction in any medium, provided the original work is properly cited. 
tank over centuries, if not millennia, is required to be assessed to evaluate the potential for residual radionuclides in the tanks to be released and adversely impact human health and the environment.

\section{Carbonation of Concrete}

As illustrated in Fig. 1, the movement of gaseous carbon dioxide $\left(\mathrm{CO}_{2}\right)$ into the partially saturated concrete pore space can initiate a series of reactions with dissolved ions and the hydrated cement paste [1]. The gaseous $\mathrm{CO}_{2}$ that enters the pore solution will partition primarily as $\mathrm{HCO}_{3}{ }^{-}$and $\mathrm{CO}_{3}{ }^{2-}$ where the resulting carbonate species react with dissolved calcium to precipitate calcite $\left(\mathrm{CaCO}_{3}\right)$ and other carbonate-based solid phases. As dissolved calcium reacts (e.g., forming calcite), the portlandite $\left(\mathrm{Ca}(\mathrm{OH})_{2}\right)$ in the cement phase dissolves, which can reduce the pore solution $\mathrm{pH}$ dramatically. Simultaneously, major constituents, including portlandite, and trace constituents will leach from the concrete to the adjacent soil.

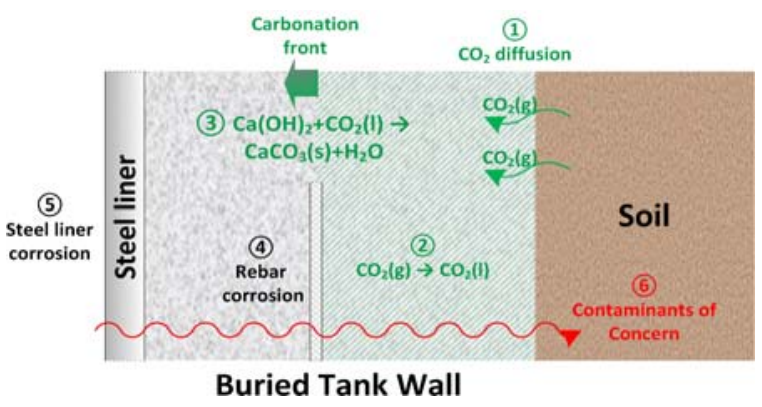

Fig. 1. Carbonation of a Representative Buried High-level Waste (HLW) Tank

\section{Impacts of Carbonation on Concrete}

The carbonation process is not necessarily detrimental and can have positive impacts (e.g., pore filling). However, carbonation, which decreases $\mathrm{pH}$, can increase leaching of certain $\mathrm{pH}$-sensitive species (i.e., those that are more soluble at lower $\mathrm{pH}$ conditions). Furthermore, the dramatic lowering of $\mathrm{pH}$ to ca. 9 [2] in the concrete pore solution can result in the loss of passivation of embedded steel including rebar, and, in the case of a high-level waste (HLW) tank, the steel liner (Fig. 1); the loss of passivation can lead to corrosion resulting in cracking and increased contaminant release from the tank interior and transport into the environment.

\section{Modeling Carbonation of Concrete}

A mechanistic model for concrete carbonation was developed by Papadakis and Fardis that considers mass transport, cement chemistry, and reaction kinetics [3]. The aforementioned mechanistic model is complex, but it can be simplified to represent carbonation as a sharp moving front. A simple analytical expression for the location, $x_{c}(\mathrm{~m})$, of the moving carbonation front as a function of cement composition and conditions, when the relative humidity is above $50 \%$, is [3]:

$$
x_{c}=A \sqrt{t}
$$

where the proportionality constant, $A$, is a function of the initial $\mathrm{CO}_{2}$ gas phase concentration, initial molar concentrations of $\mathrm{Ca}(\mathrm{OH})_{2}(\mathrm{~s})$ and $\mathrm{C}-\mathrm{S}-\mathrm{H}$ in the clinker, and effective diffusivity of $\mathrm{CO}_{2}$ in the carbonated area. A shrinking core model was developed by Walton, et al. [4] that resulted in the same relationship as in Eq. 1 (with a different proportionality constant). Experimental results have confirmed the relationship between the carbonation front and time provided in Eq. 1. 
LeachXSTM/ORCHESTRA (LXO) includes a geochemical/reactive transport model used to model the diffusion of gaseous $\mathrm{CO}_{2}$ into the unsaturated pore space of a concrete and the resulting reactions, constituent leaching, and diffusion [5,6]. Other important transport phenomena (e.g., water and associated ionic transport due to different capillary pressures across the concrete-soil interface) will be considered in future studies. A one-dimensional LXO model (Fig. 2) was used to simulate carbonation of a representative waste tank wall. LXO employs a set of homogeneous, well-mixed cells to represent the concrete tank wall. The extent of soil that is considered in the model is 1-m based on previous experience. The soil boundary condition is represented by a single well-mixed cell that contains the volume of pore water (accounting for saturation and porosity) assumed to be in near equilibrium with the pore water in the boundary cell of the concrete tank wall.

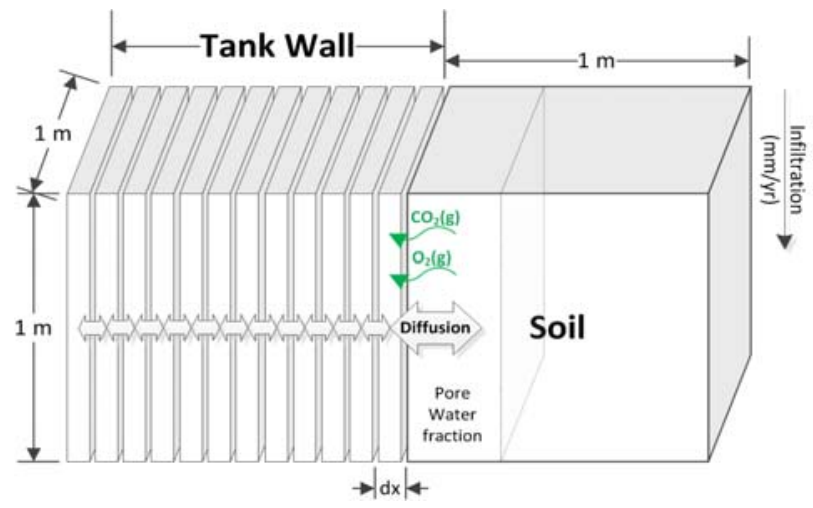

Fig. 2. Schematic Showing LeachXSTM/ORCHESTRA Implementation of the Carbonation Model

The refresh rate (for the soil pore solution in contact with the concrete) is based on the travel time (infiltration rate) of water for the area. For semi-arid conditions (e.g., those at the USDOE Hanford Site), the infiltration rate varies (with geology, hydraulic properties of the vadose zone, and rate of recharge) but is generally slow enough that a no flow boundary could be assumed. Instead, a simple refresh scheme using deionized water is employed in the model (Fig. 2).

\subsection{Parameters for the LeachXS ${ }^{\mathrm{TM}}$ /ORCHESTRA (LXO) Carbonation Model}

The infiltration rate at the Hanford Site can vary from 4 to $80 \mathrm{~mm} / \mathrm{yr}$ (0.004 to $0.08 \mathrm{~m} / \mathrm{yr})$ [7] and up to $12 \mathrm{in} / \mathrm{yr}(0.30 \mathrm{~m} / \mathrm{yr})$ at the USDOE Savannah River Site (SRS) for degraded cover systems [8]. Based on the maximum Hanford infiltration rate (corresponding to the minimum refresh time), the time $\left(T_{R}\right)$ for the soil pore solution to travel the 1-m height of the model domain (Fig. 2) would be:

$$
T_{R}=\frac{\text { height }}{\text { infiltration rate }}=\frac{1 \mathrm{~m}}{0.08 \mathrm{~m} / \mathrm{yr}}=12.5 \mathrm{yr}
$$

The pore solution in contact with the tank wall is refreshed once every 12.5 years in the model; the refresh time would be 3.33 years for a tank in soil with an infiltration rate of $0.30 \mathrm{~m} / \mathrm{yr}$. These rates are infrequent but are based on measured infiltration rates and appear reasonable based on the slow nature of the carbonation process.

The volume of water $\left(V_{R}\right)$ assumed to be in contact with the tank wall and in near equilibrium with the tank wall pore solution is needed for the LXO model. Estimates of soil porosity $\left(\phi_{\text {soil }}\right)$ and saturation $\left(S_{\text {soil }}\right)$ can be used to estimate this volume. Measured porosities of Hanford soils vary widely; however, median values cluster around $0.38[9,10]$. Thus assuming soil porosity $\left(\phi_{\text {soil }}\right)$ of 0.38 and saturation $\left(S_{\text {soil }}\right)$ of $50 \%$ (to allow movement of soil gas) for the $V_{\text {soil }}$ indicated in Fig. 2, the contact volume $\left(V_{R}\right)$ would be: 


$$
V_{R}=S_{\text {soil }} \varphi_{\text {soil }} V_{\text {Soil }}=(0.5)(0.38)(1 \mathrm{~m})^{3}\left(\frac{1000 \mathrm{~L}}{1 \mathrm{~m}^{3}}\right)=190 \mathrm{~L}
$$

Similarly, the pore solution volume in contact with an SRS HLW tank wall would be $185 L$ (for a porosity of 0.37 [8]). Because of the similarity, a refresh volume of $190 \mathrm{~L}$ (refreshed every 12.5 years based on Eq. 3) is used in this study.

Another important parameter in the model is the effective diffusivity $\left(\mathrm{D}_{\mathrm{CO} 2}\right)$ for $\mathrm{CO}_{2}$. Various studies suggest a range of potential values for $\mathrm{D}_{\mathrm{CO} 2}$ depending on the nature of the concrete including cement paste pore volume, cement and water content, and temperature [11]. The model used in this study was found to be sensitive to the $\mathrm{CO}_{2}$ diffusivity. Although the effective diffusivity changes with certain parameters studied (i.e., concrete saturation), an effective diffusivity $\left(1 \times 10^{-6} \mathrm{~m}^{2} / \mathrm{s}\right)$ was selected near the lower part of the potential range as a starting point for modeling. Additional investigation is planned to evaluate the causes for the sensitivity and impact of diffusivity.

The simulation duration was based on the need to consider tank integrity and closure scenarios. Construction of USDOE HLW tanks began in the early 1940s, and the last such tanks are scheduled to be closed in 2052 [12]. Thus tank integrity considerations are on the order of 100 years. For tank closure, the rate at which carbonation progresses through the tank wall suggests the duration needed for simulations. Since the carbonation rate is not known, an approximate rate of $0.001 \mathrm{~m} / \mathrm{yr}$ for highquality concrete was used to estimate the simulation duration. The thicknesses of Hanford HLW tank walls vary from 0.30 to $0.61 \mathrm{~m}$ (12 to 24 inches) with most having a $0.30-\mathrm{m}$ thickness [13]. The Savannah River HLW tank wall thicknesses vary from 0.18 to $0.84 \mathrm{~m}$ (7 to 33 inches) with most having a 0.76-m thickness [14]. Thus the simulation might need to be run for over 600 years for Hanford HLW tanks and over 800 years for SRS tanks (depending on the carbonation rate). Because of the number of simulations needed, a 0.30 -m wall thickness and 600-year duration are used.

One important parameter in the carbonation model is the soil-gas $\mathrm{CO}_{2}$ concentration that drives the movement of $\mathrm{CO}_{2}$ into the concrete wall. The concentration of $\mathrm{CO}_{2}$ in the atmosphere is $0.038 \%$. However, Hanford HLW tanks are buried under $1.5 \mathrm{~m}$ of soil; measurements indicate that the concentration of $\mathrm{CO}_{2}$ at this depth can be up to $2.4 \%$ [15]. For SRS tanks, the average soil-gas $\mathrm{CO}_{2}$ concentration is approximately 1\% [16]. Laboratory testing is often carried out at $5 \% \mathrm{CO}_{2}$.

\subsection{Materials Used in Carbonation Modeling}

Two scenarios are considered in this paper: USDOE HLW tank integrity and closure. Construction of the tanks began in the 1940s and was completed in the mid-1980s. Some information for the concretes used in HLW tank construction is available [14]; however, the properties of the materials have not been tested using modern methods. Thus a set of tested materials (Table 1) used in USDOE applications was studied to likely bracket the responses of actual tank construction materials.

Table 1. Materials Considered in this Report (wt\%). All materials characterized except for silica fume (SF); a representative composition was used for this material.

\begin{tabular}{|c|c|c|c|c|c|}
\hline Material & HPC & BGM & SVC & VCO & VCT \\
\hline Blast Furnace Slag (BFS) & 0.00 & 13.48 & 8.03 & 7.12 & 7.31 \\
\hline Fly Ash - Type F (FAF) & 0.00 & 6.62 & 16.93 & 0.00 & 4.29 \\
\hline Ordinary Portland Cement (OPC) & 22.20 & 5.40 & 5.40 & 10.75 & 5.60 \\
\hline Silica Fume (SF) & 0.00 & 0.00 & 0.00 & 0.00 & 1.22 \\
\hline Quartz Sand (QS) & 66.70 & 62.25 & 55.02 & 29.12 & 24.73 \\
\hline Gross Aggregate (GA) & 0.00 & 0.00 & 0.00 & 46.19 & 50.14 \\
\hline Water & 11.10 & 11.76 & 14.62 & 6.83 & 6.86 \\
\hline
\end{tabular}

HPC - Hydrated Portland Cement

SVC - Standard Vault Concrete

BGM - Backfill Grout Material 
The vault concretes (VCO and VCT) are characterized materials representative of those used for the SRS Saltstone low-activity waste (LAW) vaults. The Backfill Grout Material (BGM) was developed to study HLW tank closure grouts. According to available information, some HLW tank walls were constructed with Portland cement and others with higher strength concretes, similar to the materials in Table 1. For this study, high porosity (30\%), low tortuosity (1.5), and highly saturated (90\%) versions of the materials were used to allow simulation times to be manageable. Tests runs are made to demonstrate the impact of these selected properties and other parameters on the results.

\subsection{Mineral Set Selected for LeachXS ${ }^{\mathrm{TM}} /$ ORCHESTRA (LXO) Carbonation Modeling}

The LXO model estimates solid-liquid equilibrium assuming a set of minerals that may be present in the system. The starting point for modeling in this paper is the set of non-clinker cement minerals (Table 2) developed for Portland cements by Lothenbach, et al. [17]. Formation of C-S-H is modeled using an ideal solid solution with Jennite-like $\left(\mathrm{C}_{1.67} \mathrm{SH}_{2.1}\right)$ and Tobermorite-like $\left(\mathrm{C}_{0.8} \mathrm{SH}_{1.3}\right)$ endmember phases as described by Arnold, et al. [18]. Adsorption of $\mathrm{K}+$ and $\mathrm{Na}+$ onto $\mathrm{C}-\mathrm{S}-\mathrm{H}$ was modeled using partition coefficients fitted to experimental data [19].

Table 2. Phases in "cemdata2007” Data Set from Lothenbach, et al. [17]. Mineral names are given in shorthand: $\mathrm{C}-\mathrm{CaO}, \mathrm{A}-\mathrm{Al}_{2} \mathrm{O}_{3}, \mathrm{~S}-\mathrm{SiO}_{2}, \mathrm{~F}-\mathrm{Fe}_{2} \mathrm{O}_{3}, \mathrm{~s}-\mathrm{SO}_{3}, \mathrm{c}-\mathrm{CO}_{3}^{-2}, \mathrm{M}-\mathrm{MgO}, \mathrm{H}-\mathrm{H}_{2} \mathrm{O}$. AFm is monosulfoaluminate.

The two highlighted phases are evaluated in the revised mineral set for carbonation modeling.

\begin{tabular}{|c|c|c|c|c|}
\hline $\begin{array}{c}\mathrm{Mg}(\mathrm{OH})_{2} \\
\text { Brucite }\end{array}$ & $\begin{array}{c}\mathrm{Ca}(\mathrm{OH})_{2} \\
\text { Portlandite }\end{array}$ & $\begin{array}{c}\mathrm{C}_{3} \mathrm{AH}_{6} \\
\text { Hydrogarnet }\end{array}$ & $\begin{array}{c}\mathrm{C}_{4} \mathrm{Ac}_{0.5} \mathrm{H}_{12} \\
\text { Hemicarbonate }\end{array}$ & $\begin{array}{c}\mathrm{C}_{6} \mathrm{As}_{3} \mathrm{H}_{32} \\
\text { (Al-)Ettringite }\end{array}$ \\
\hline $\begin{array}{c}\mathrm{CaSO}_{4} \cdot 2 \mathrm{H}_{2} \mathrm{O} \\
\text { Gypsum }\end{array}$ & $\begin{array}{l}\mathrm{CaCO}_{3} \\
\text { Calcite }\end{array}$ & $\begin{array}{c}\mathrm{C}_{3} \mathrm{FH}_{6} \\
\text { Fe-hydrogarnet }\end{array}$ & $\begin{array}{c}\mathrm{C}_{4} \mathrm{Fc}_{0.5} \mathrm{H}_{12} \\
\text { Fe-hemicarbonate }\end{array}$ & $\begin{array}{c}\mathrm{C}_{6} \mathrm{Fs}_{3} \mathrm{H}_{32} \\
\text { Fe-ettringite }\end{array}$ \\
\hline $\begin{array}{c}\mathrm{SiO}_{2}(\mathrm{am}) \\
\text { Amorphous } \\
\text { Silica }\end{array}$ & $\begin{array}{l}\mathrm{C}_{2} \mathrm{ASH}_{8} \\
\text { Strätlingite }\end{array}$ & $\begin{array}{c}\mathrm{C}_{3} \mathrm{AS}_{0.8} \mathrm{H}_{4.4} \\
\text { Siliceous } \\
\text { Hydrogarnet }\end{array}$ & $\begin{array}{c}\mathrm{C}_{4} \mathrm{AcH}_{11} \\
\text { Monocarbonate }\end{array}$ & $\begin{array}{c}\mathrm{C}_{6} \mathrm{Ac}_{3} \mathrm{H}_{32} \\
\text { Tricarboaluminate }\end{array}$ \\
\hline $\begin{array}{c}\mathrm{Al}(\mathrm{OH})_{3}(\mathrm{am}) \\
\text { Amorphous } \\
\text { Gibbsite }\end{array}$ & $\begin{array}{c}\mathrm{C}_{2} \mathrm{FSH}_{8} \\
\text { Fe-strätlingite }\end{array}$ & $\begin{array}{c}\mathrm{C}_{4} \mathrm{AH}_{13} \\
\text { Hydroxy } A F m\end{array}$ & $\begin{array}{c}\mathrm{C}_{4} \mathrm{FCH}_{12} \\
\text { Fe-monocarbonate }\end{array}$ & $\begin{array}{l}\mathrm{M}_{4} \mathrm{AH}_{10} \\
\text { Hydrotalcite }\end{array}$ \\
\hline $\begin{array}{c}\mathrm{Al}_{2} \mathrm{O}_{3} \\
\text { Alumina }\end{array}$ & $\begin{array}{c}\mathrm{C}_{2} \mathrm{AH}_{8} \\
\text { Unnamed } \\
\text { metastable phase }\end{array}$ & $\begin{array}{c}\mathrm{C}_{4} \mathrm{FH}_{13} \\
\text { Fe-hydroxy AFm }\end{array}$ & $\begin{array}{l}\mathrm{C}_{4} \mathrm{AsH}_{12} \\
\text { Monosulfate }\end{array}$ & $\begin{array}{c}\mathrm{M}_{4} \mathrm{FH}_{10} \\
\text { Fe-hydrotalcite }\end{array}$ \\
\hline $\begin{array}{c}\mathrm{Fe}(\mathrm{OH})_{3}(\mathrm{mcr}) \\
\text { Microcrystalline } \\
\mathrm{Fe}(\mathrm{OH})_{3}\end{array}$ & $\begin{array}{c}\mathrm{C}_{2} \mathrm{FH}_{8} \\
\text { Unnamed } \\
\text { metastable phase }\end{array}$ & \multirow{2}{*}{$\begin{array}{c}\text { Solid Solution: } \\
\mathrm{C}_{1.67} \mathrm{SH}_{2.1} \\
\text { Jennite } \\
\mathrm{C}_{0.83} \mathrm{SH}_{1.3} \\
\text { Tobermorite }\end{array}$} & $\begin{array}{c}\mathrm{C}_{4} \mathrm{FsH}_{12} \\
\text { Fe-monosulfate }\end{array}$ & $\begin{array}{c}\mathrm{M}_{4} \mathrm{AcH}_{9} \\
\text { CO }_{3} \text {-hydrotalcite }\end{array}$ \\
\hline $\begin{array}{c}\mathrm{Fe}_{2} \mathrm{O}_{3} \\
\text { Ferric oxide }\end{array}$ & $\begin{array}{c}\mathrm{CaSO}_{4} \\
\text { Anhydrite }\end{array}$ & & & \\
\hline
\end{tabular}

The binders (Table 1) used to make the materials studied have been extensively characterized. Reacted fractions for the OPC, FAF, and BFS were estimated to be 85, 0, and 80\%, respectively, for the HPC and vault concretes (cured for 3 months) [18]. The silica fume (SF) was not characterized; a representative composition and $100 \%$ reactivity were assumed for this study.

Material characterization included testing using Method 1313 [19] from the U.S. Environmental Protection Agency's Test Methods for Evaluating Solid Waste, Physical/Chemical Methods, SW-846 (http://www.epa.gov/). Method 1313 is a leaching characteristic method that provides the intrinsic material parameters that control leaching of species of interest under equilibrium conditions and is intended to be used as part of an environmental assessment to evaluate disposal, beneficial use, treatment effectiveness, and remedial options. Nine eluate solutions are prepared $(2 \leq \mathrm{pH} \leq 13)$ on particle-size reduced specimens (to facilitate the approach to solid-liquid equilibrium) that represent the liquid-solid partitioning curve of constituents as a function of $\mathrm{pH}$. Dilute acid or base is added to deionized water to achieve final eluate $\mathrm{pH}$ values, and the results are plotted to assess quality control 
and to provide a titration curve. A very wide range of materials, including those in Table 1 , have been evaluated and are described in LeachXSTM.

Measured eluate concentrations for the materials in Table 1 were evaluated versus corresponding predictions using a LXO model developed to represent Method 1313. For the sake of brevity, only the HPC comparisons are provided here (Fig. 3); however, the ability to describe the Method 1313 results for bulk species is also shown for the blended cements in Table 1; the Lothenbach, et al. mineral set [17] thus appears to be a reasonable first approximation to describe the USEPA Method 1313 results for these materials. Different mineral sets may provide better descriptions of the behavior of these materials.

A variation on the full mineral set was evaluated (Fig. 3): 1) omitting ferric oxide $\left(\mathrm{Fe}_{2} \mathrm{O}_{3}\right)$ because of the poor ability to predict iron solubilities across the range of $\mathrm{pH}$ and 2) omitting siliceous hydrogarnet $\left(\mathrm{C}_{3} \mathrm{AS}_{0.8} \mathrm{H}_{4.4}\right)$ because it is likely slow to precipitate and dissolve [18]. The results indicate an improved ability to predict iron solubility and reasonable trade-offs between predictions for aluminium and magnesium solubilities for all materials (Table 1). The revised set of minerals was selected for use in carbonation modeling because the predicted magnesium solubilities were not deleteriously impacted and the predicted aluminium solubilities were improved for the materials studied for the range of $\mathrm{pH}(>9)$ important in this study. Consideration of additional solid solutions will be investigated in the future to improve predictions.
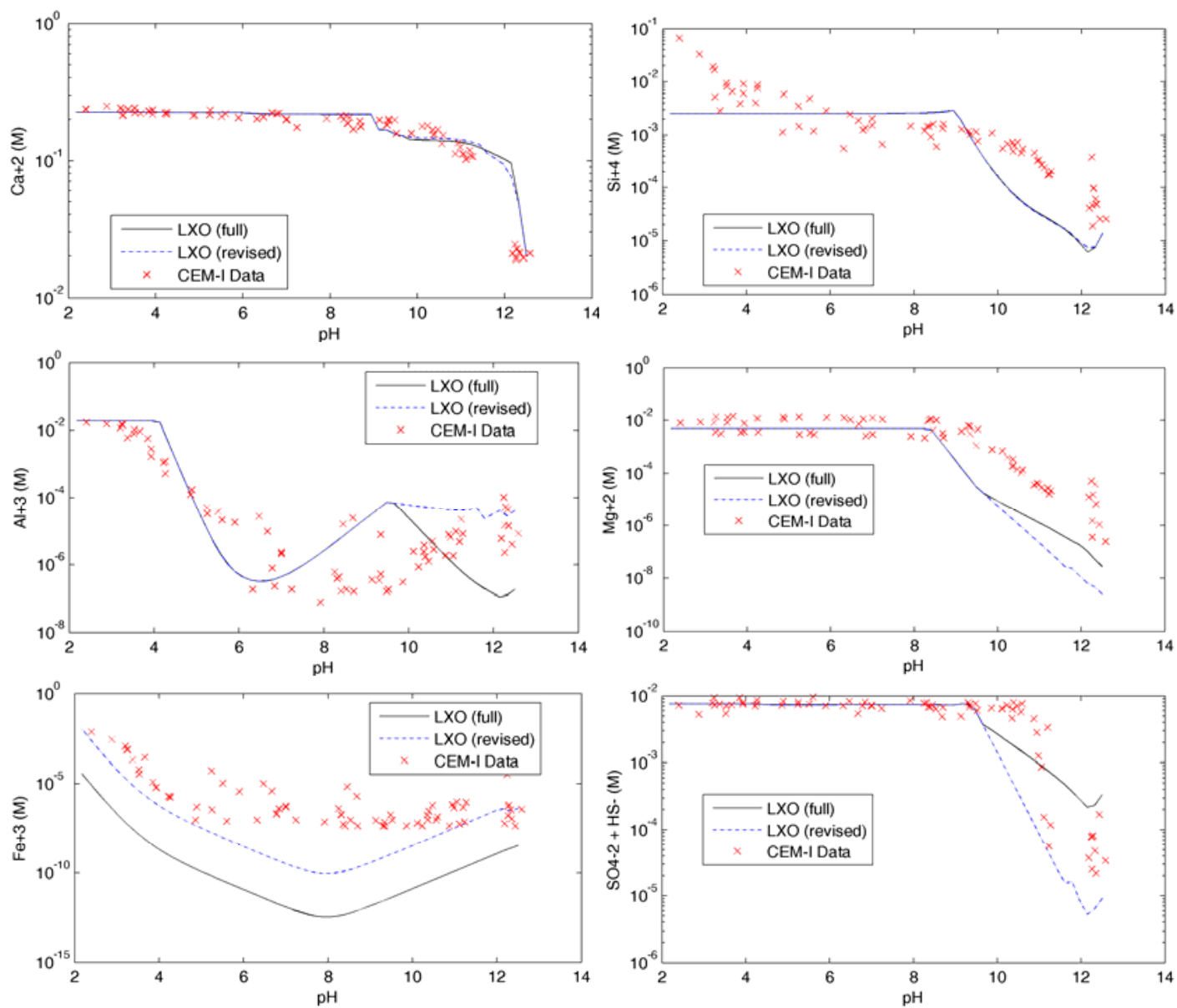

Fig. 3. Modeling USEPA Method 1313 Results using LeachXSTM/ORCHESTRA (LXO) for Portland Cements. The full set of phases described by Lothenbach, et al. [17] is compared to a set omitting $\mathrm{Fe}_{2} \mathrm{O}_{3}$ and $\mathrm{C}_{3} \mathrm{AS}_{0.8} \mathrm{H}_{4.4}$. 


\subsection{Carbonation Modeling of a HLW Tank using LeachXS ${ }^{\mathrm{TM}}$ /ORCHESTRA (LXO)}

LeachXSTM/ORCHESTRA is used to model the penetration of gaseous $\mathrm{CO}_{2}$ into the uncracked, partially saturated concrete wall of a representative HLW tank, the resulting carbonation reactions, and constituent leaching. Although carbonation itself does not necessarily have a deleterious effect on concrete, only the impacts on constituent leaching, $\mathrm{pH}$ (which can depassivate embedded steel and accelerate corrosion leading to cracking), and transport are considered here. Any potential positive impacts related to carbonation (e.g., pore filling) will be considered subsequently.

Simulations were run at $2.4 \% \mathrm{CO}_{2}$ (Hanford) in the soil-gas at $90 \%$ concrete saturation; Fig. 4 illustrates the evolution of $\mathrm{pH}$ during the first 600 years for HPC (minimum $\mathrm{pH}$ change) and VCT (maximum pH change). The HPC and VCT responses tend to bracket those for the materials studied; note that the decreased $\mathrm{pH}$ response through the material is related to $\mathrm{CO}_{2}$ movement through the material. Fig. 5 shows the impact of concrete composition (Table 1) on the depth to which the $\mathrm{pH}$ is lowered to 9; the VCT depth is approximately five times that of the HPC. Results for materials with the least OPC binder added (Table 1) show expected approximate linear relationship with root time; responses for HPC and VCO appear more complicated and may be due to the refresh scheme used in the model. The carbonation depth (0.001-0.002 $\mathrm{m}$ in 65 years) for a dome core from the Hanford C107 HLW tank [20] appears to reasonably agree with predictions, considering uncertainties in field conditions and likely differences among assumed and actual transport parameters.

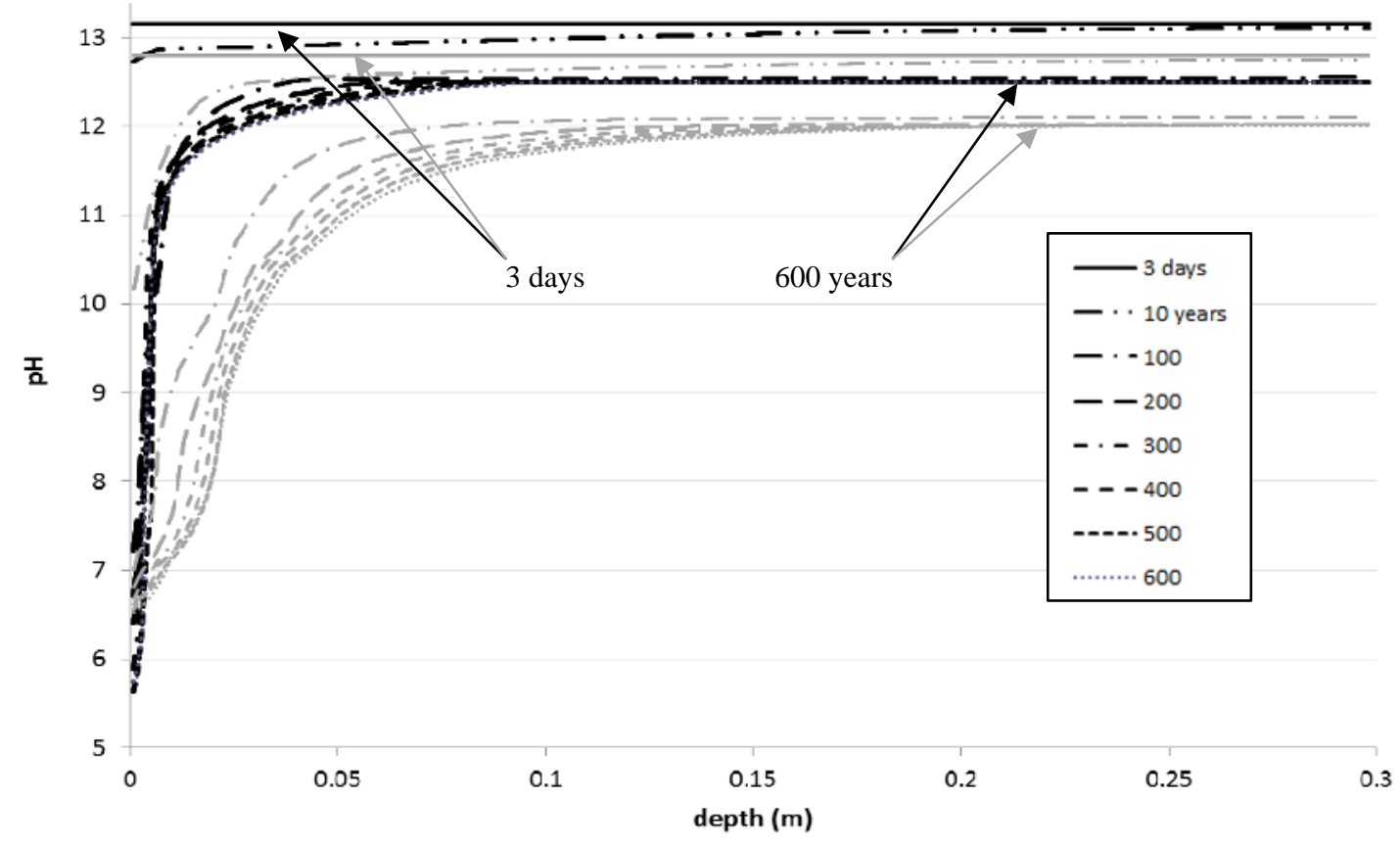

Fig. 4. Evolution of pH for HPC (black) and VCT (grey) for $2.4 \%$ Soil-Gas $\mathrm{CO}_{2}$ and $90 \%$ Saturation.

The soil-gas $\mathrm{CO}_{2}$ boundary concentration is the primary driver for the movement of $\mathrm{CO}_{2}$ into the pore structure of the concrete wall and thus significantly impacts carbonation of the material. Fig. 6 shows the impact of $\mathrm{CO}_{2}$ concentration on the depth to which pH is less than 9 for HPC and VCT. For $5 \% \mathrm{CO}_{2}$ in soil-gas, the VCT $\mathrm{pH}$ was lowered to $\mathrm{pH} 9$ to a depth of less than $0.035 \mathrm{~m}$ (35 mm) over the first 600 years; the other materials were carbonated to a lesser degree and depth. The difference between $1 \%$ and $5 \% \mathrm{CO}_{2}$ in soil-gas roughly doubles the effect. Note that as the $\mathrm{CO}_{2}$ concentration approaches that of atmospheric conditions $(0.038 \%)$, there is little carbonation predicted during the first 600 years. In many cases, it requires decades to have significant predicted carbonation in a buried HLW tank wall, which is confirmed by the Hanford dome core analysis. 


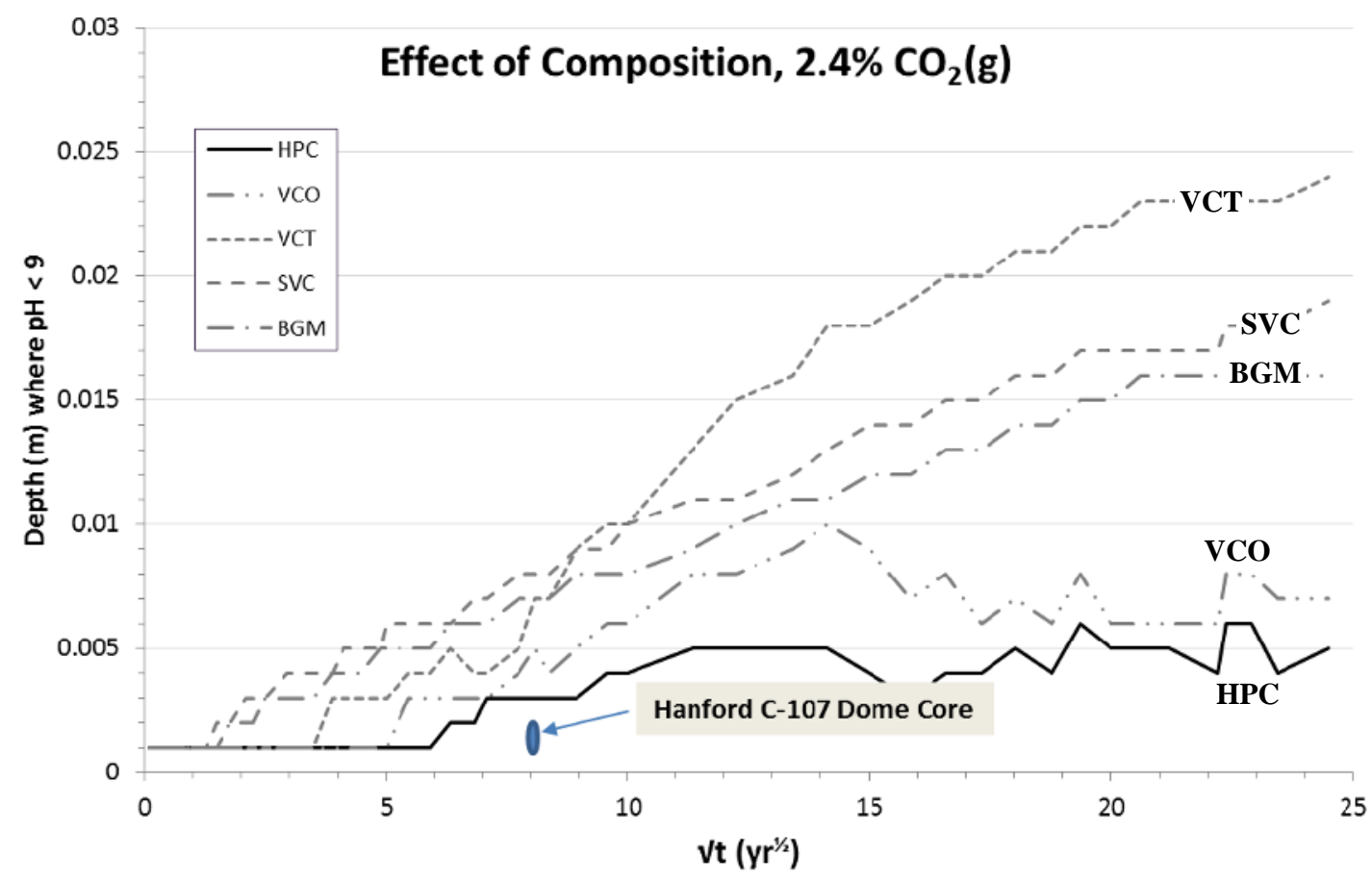

Fig. 5. Carbonation Model Results (2.4\% Soil-Gas $\mathrm{CO}_{2} ; 90 \%$ Saturation) for the Materials Studied.

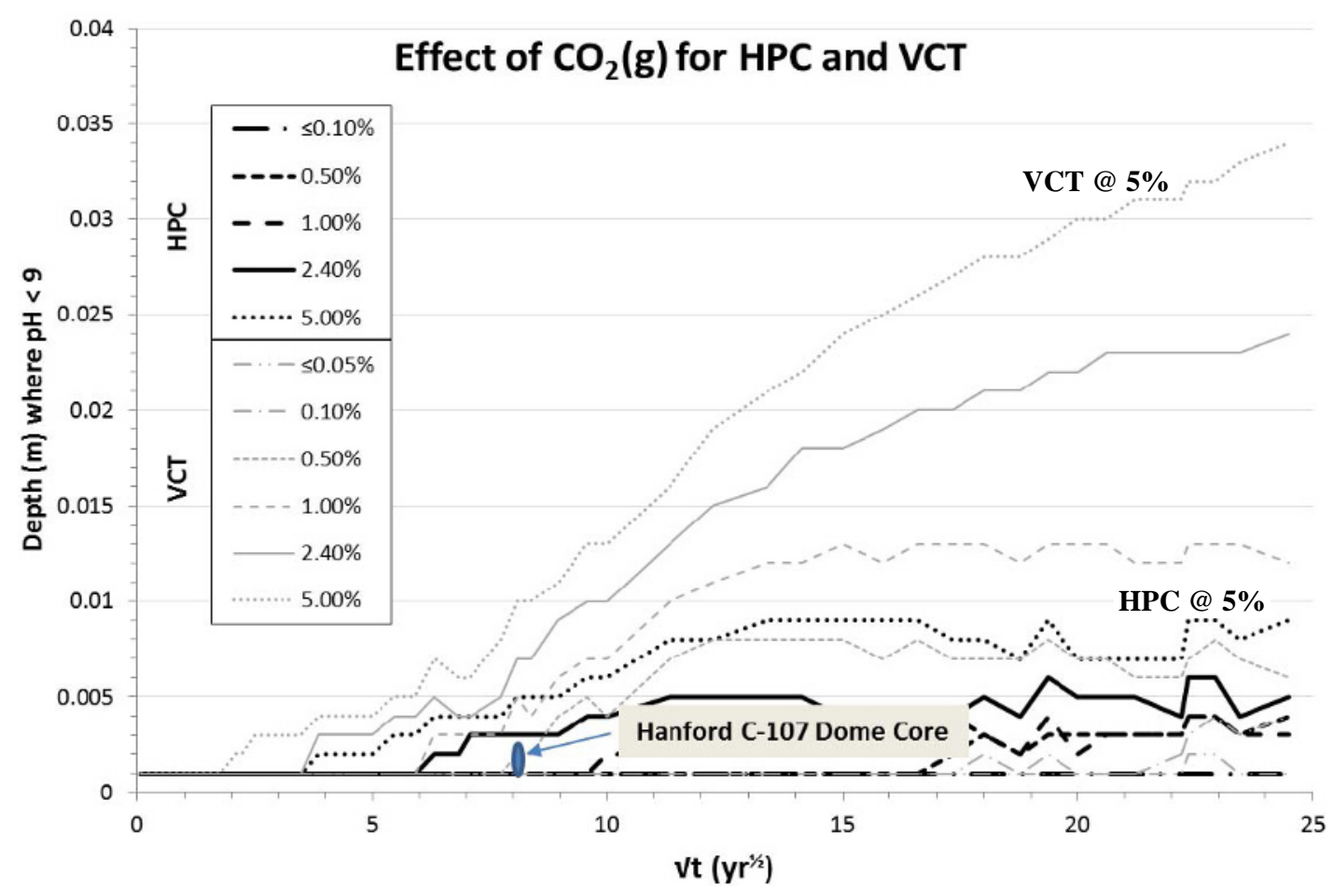

Fig. 6. Results for HPC and VCT as a Function of Soil-Gas $\mathrm{CO}_{2}$ Concentration (90\% Saturation) 
Additional parameters including concrete saturation, porosity, $\mathrm{CO}_{2}$ effective diffusivity, mineral set, and thermodynamic parameters were varied to evaluate their relative impacts on predicted carbonation. For example, the concrete saturation has an impact (Fig. 7) on predicted carbonation (to $\mathrm{pH}<9$ ) similar to composition or soil-gas $\mathrm{CO}_{2}$ concentration. Larger effective diffusivities appear to have significant impacts on both the initiation of carbonation and the degree to which the material is carbonated. Additional modeling work is needed to quantify the effects of diffusivity. On the other hand, results were not highly sensitive to changes in the refresh scheme (Hanford versus SRS refresh volume and frequency); however, additional modeling work will be done to evaluate potential impacts of the refresh scheme on predicted carbonation results.

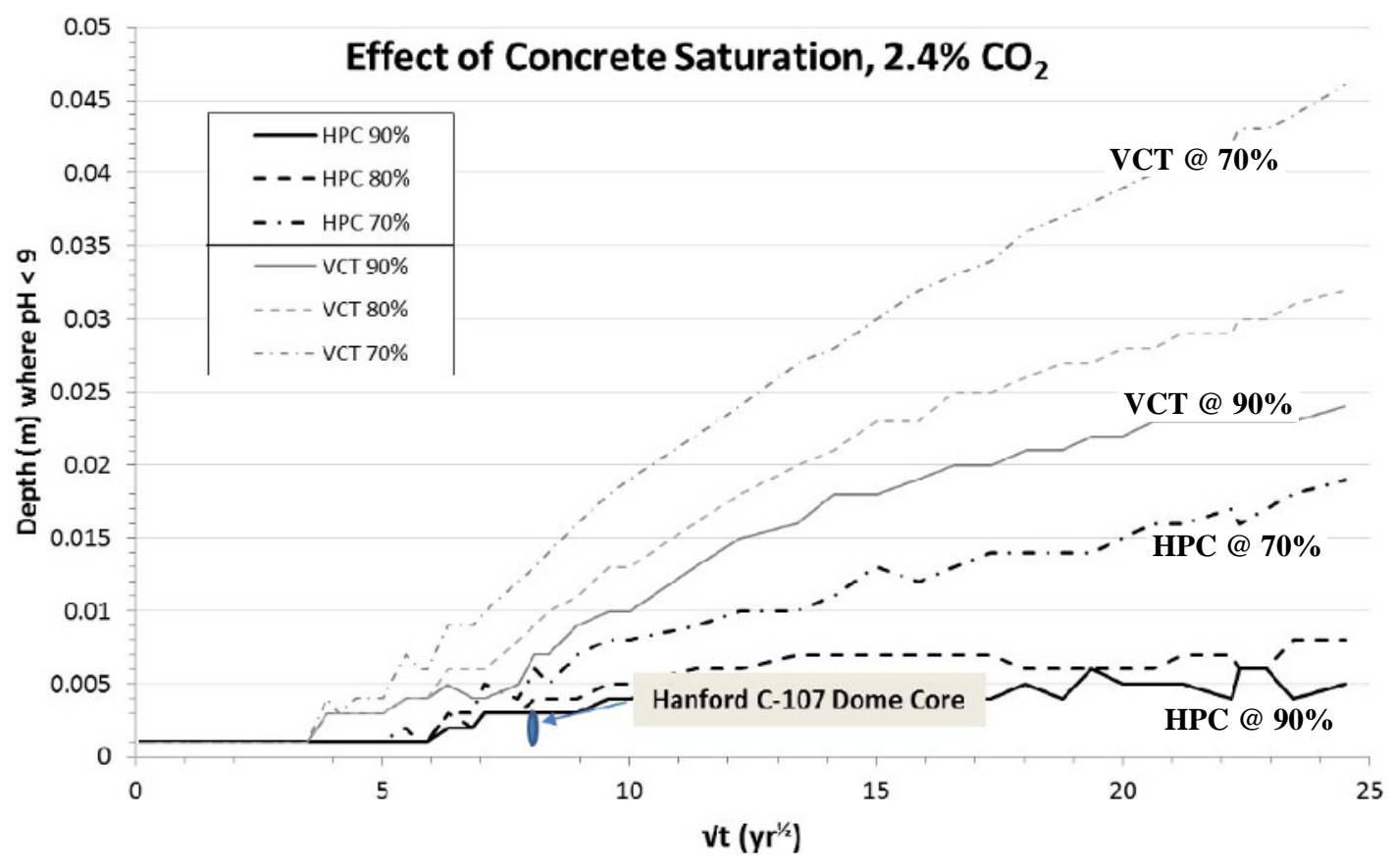

Fig. 7. Results for HPC and VCT as a Function of Concrete Saturation $\left(2.4 \% \mathrm{CO}_{2}\right)$

\section{Conclusions}

A LeachXS/ORCHESTRA geochemical/reactive transport model was used to evaluate carbonation for integrity and closure of a representative USDOE high-level waste (HLW) tank. Carbonationinduced corrosion has been identified as an important degradation and possible failure mechanism for HLW tanks. Parameters including composition, soil-gas $\mathrm{CO}_{2}$ concentration, concrete saturation, porosity, $\mathrm{CO}_{2}$ effective diffusivity, mineral set, and thermodynamic parameters were varied to evaluate sensitivity of the resulting predicted carbonation results. All impacts tend to have less than an order of magnitude effect on predicted carbonation (to $\mathrm{pH}<9$ where embedded steel can be depassivated) and most effects are predicted to be less than five times the original results over the 600 years evaluated.

\section{Acknowledgements}

This paper was prepared with the financial support by the U. S. Department of Energy (DOE), under Cooperative Agreement Number DE-FC01-06EW07053 entitled 'The Consortium for Risk Evaluation with Stakeholder Participation III' awarded to Vanderbilt University. This work was also 
supported by the U. S. DOE under Interagency Agreement No. DE-AI09-09SR22667 to Savannah River National Laboratory managed by Savannah River Nuclear Solutions. This research was carried out as part of the Cementitious Barriers Partnership supported by the U.S. DOE Office of Environmental Management. The opinions, findings, conclusions, or recommendations expressed herein are those of the authors and do not necessarily represent the views of the Department of Energy or Vanderbilt University.

\section{References}

1. E. Samson, P. Henocq J. Marchand, CBP-TR-2009-002-C4, Rev.0, SIMCO Technologies, Inc.; Cementitious Barriers Partnership, Quebec City, Canada (2009)

2. C. L. Page, K. W. J. Treadway, Nature, 1982. 297 (1982)

3. V. G. Papadakis, M. N. Fardis, AIChE Journal, 35, 10 (1989)

4. Walton, J. C., L. E. Plansky, R. W. Smith, NUREG/CR-5542 (1990)

5. LeachXS User's Guide: LeachXS Pro Version 1.3.5, Energy Research Centre of The Netherlands, Petten, The Netherlands (2012)

6. J.C.L Meeussen, Env. Sci. \& Tech. 37, 6 (2003)

7. Maher, K., D. J. DePaolo, M. E. Conrad, R. J. Serne, Water Resour. Res. 39, 8 (2003)

8. M.A. Phifer, K.L. Dixon, SRNL-STI-2009-00316, Savannah River National Laboratory, Aiken, SC (2009)

9. A.G. Hunt, G.W. Gee, Vadose Zone Journal 2, (2003)

10. R.J. Serne, D.F. Rucker, A.L. Ward, D.C. Lanigan, W. Um, M.W. Benecke, B.N. Bjornstad, PNNL-17821, Pacific Northwest National Laboratory, Richland, WA (2009)

11. S. Talukdar, N. Banthia, J.R. Grace, Cement Concrete Comp In Press (2012)

12. Hanford Facility Agreement and Consent Order, as amended, Washington State Department of Ecology, U. S. Environmental Protection Agency, and U. S. Department of Energy, Olympia, WA (1998)

13. B.V. Winkel, RPP-10435, CH2MHILL Hanford Group, Inc., Richland, Washington (2002)

14. C.A. Langton, SRNL-STI-2010-00035, Rev. 0, Savannah River National Laboratory, Aiken, SC (2010)

15. B.D. Wood, C.K. Keller, D.L Johnstone, Cem. Concr. Res. 29, 3 (1993)

16. M. Millings, SRNL-L3200-2012-00017, Savannah River National Laboratory, Aiken, SC (2012)

17. B. Lothenbach, T. Matschei, G. Möschner, F. P. Glasser, Cem. Concr. Res. 38, 1 (2008)

18. J. Arnold, D.S. Kosson, , K.G. Brown, J.C.L. Meeussen, H. A. van der Sloot, NUCPERF 2012, Cadarache, France (2012)

19. A.C. Garrabrants, D.S. Kosson, L. Stefanski, R. DeLapp, P.F.A.B. Seignette, H.A. van der Sloot, P. Kariher, M. Baldwin, EPA/600/R-12/623, U.S. Environmental Protection Agency, Washington, DC (2012)

20. M.W. Rinker, J.B. Johnson, R.S. Rast, D.J. Washenfelder, WRPS-51711-FP, Rev. 0, WM'2012, WMSymposia, Phoenix, Arizona (2012) 